\title{
Beach morphodynamic impact on a macrobenthic community along a subtidal depth gradient
}

\author{
M. Dolbeth ${ }^{1, *}$, Ó. Ferreira ${ }^{2}$, H. Teixeira ${ }^{1}$, J. C. Marques ${ }^{1}$, J. A. Dias ${ }^{2}$, M. A. Pardal ${ }^{1}$ \\ ${ }^{1}$ Institute of Marine Research (IMAR), c/o Department of Zoology, University of Coimbra, 3004-517 Coimbra, Portugal \\ ${ }^{2}$ FCMA/CIMA, Universidade do Algarve, Campus de Gambelas, 8005-139 Faro, Portugal
}

\begin{abstract}
The subtidal macrobenthic community of a temperate beach in southern Portugal was studied along a depth gradient (1.3 to $32 \mathrm{~m}$ deep), which was long enough to comprise both highly hydrodynamic and calmer areas, to assess the influence of the spatial and temporal differences in hydrodynamic impact at the seafloor on the organization of a macrobenthic community. These differences were assessed by studying the variations in wave climate, depth of closure and extension of the mixed profile. A spatial zonation was detected from highly hydrodynamic shallow depths, $7.2 \mathrm{~m}$ deep shorewards, to the calmer deeper areas, from $8.4 \mathrm{~m}$ seawards. Accordingly, in the shallowest depths, species richness and densities were lower, with the inhabiting species, mainly crustaceans and surf clams, adapted to the environmental severity. Both species richness and densities increased along the depth gradient, and the community became dominated by polychaetes, nematodes and nemerteans. Seawards, within the relict sediments (deeper than $25 \mathrm{~m}$ ), species richness and abundance decreased again. The community patterns also changed in response to the occurrence of strongly hydrodynamic episodes (such as storms), which had a higher impact than the seasonality. It was concluded that harsh physical environmental conditions reduce species richness, both spatially and temporally. With respect to density, other parameters related to life cycle characteristics, recruitment success and biotic interactions may also have some impact.
\end{abstract}

KEY WORDS: Subtidal beach $\cdot$ Wave climate $\cdot$ Morphodynamics $\cdot$ Macrobenthic community $\cdot$ Spatial zonation · Temporal patterns

Resale or republication not permitted without written consent of the publisher

\section{INTRODUCTION}

Several studies have reported on the global patterns of the sandy beach benthic communities and their conditionings (Brazeiro 2001, Rodil \& Lastra 2004, Defeo \& McLachlan 2005, Janssen \& Mulder 2005, McLachlan \& Dorvlo 2005, Lastra et al. 2006, Rodil et al. 2006). Less frequent are the studies on the swash, surf (Vicente \& Sorbe 1999, Beyst et al. 2001a,b) and sub-littoral areas (Morin et al. 1985, Hernández-Arana et al. 2003, Wieking \& Kröncke 2003, Connor et al. 2004, Hoey et al. 2004, Janssen \& Mulder 2005), due to constraints in the sampling procedures near the wave breaking and sub-littoral regions. In these areas, the sediment texture and dynamics are assumed to have a major role in the structure of the benthic community
(Snelgrov 1998, Miller et al. 2002, Hoey et al. 2004). Disturbance events, physical and/or anthropogenically induced, constitute an important source of temporal and spatial heterogeneity, changing the sediment characteristics and allowing colonization by new individuals (Dernie et al. 2003, Hewitt et al. 2003). Biological interactions, such as life cycle characteristics, predation, competition and bioturbation are also recognised to play an important role in the benthic community regulation patterns (Snelgrov 1998, Reise 2002, Hewitt et al. 2003).

The biological and physical interactions on the inner shelf generally depend on the waves and tidal range (Rosenberg, 1995, Snelgrove et al. 1998, Hewitt et al. 2003). The amount of the mixing and erosion of sediment will be driven by the waves and tidal trans- 
port, varying with large and small spatial changes in hydrodynamics (Hewitt et al. 2003). Seasonal differences in the hydrodynamics or punctual disturbance events, such as storms, may be an important conditioning for the benthic community (Hernández-Arana et al. 2003). The wave climate impact on the sea bottom can be expressed in terms of the depth of closure $\left(D_{c}\right)$, i.e. the depth below which limited sediment transport due to wave action is expected to occur (Nicholls et al. 1998). Thus, the $D_{c}$ separates the active cross-shore profile from a deeper zone where the sediment transport is much weaker and morphological changes are less perceptible. As a result, the $D_{c}$ can be seen as a proxy of the wave energy acting at a given shoreface. Deeper values of $D_{c}$ are associated with higher wave energy levels and sediment exchanges, while shallower values result from lower wave energy and consequent smaller degree of sediment transport and morphological changes. The macrobenthic community existing at the nearshore must be able to adapt to the different wave energies and to the consequent sediment mixing, resulting in changes to the spatial and temporal distribution patterns.

In the present study, the coastal macrobenthic community was examined along a depth gradient long enough to comprise both highly hydrodynamic and calmer areas. The main objective was to assess the response of the macrobenthic community to both spatial and temporal (seasonal) differences in hydrodynamics. For this purpose, both the physical and biological (namely macrobenthic communities) envi- ronments were studied spatially and throughout different annual seasons. To our knowledge, no study has reported on the impact of the differences in the hydroand morphodynamic patterns through time on a macrobenthic community, taking into consideration a depth gradient including both highly hydrodynamic areas (e.g. surf zones) and less hydrodynamic sublittoral/nearshore areas.

\section{MATERIALS AND METHODS}

Study site. The study was conducted in the Ancão Peninsula (Fig. 1), the western limit of the Ria Formosa (Algarve, Portugal). The Ria Formosa is a barrier island system composed of 5 islands and 2 peninsulas, separated by inlets (Fig. 1). Tides are semi-diurnal with a mean tidal range of about $2.5 \mathrm{~m}$ and a maximum of about $3.5 \mathrm{~m}$. Dominant wave direction is from WSW, and the study area is directly exposed. The wave energy can be considered as moderate, with an average annual significant wave height $\left(\mathrm{H}_{\mathrm{s}}\right)$ of $0.92 \mathrm{~m}$ (Costa et al. 2001). Storm conditions $\left(\mathrm{H}_{\mathrm{s}}>3 \mathrm{~m}\right)$ do not exceed $2 \%$ of the wave records, with values $>5 \mathrm{~m}$ representing about $0.2 \%$ of the records (Costa et al. 2001). The beach can be classified as 'Low Tide Terrace + Rip', with a reflective to intermediate behaviour (Ferreira et al. 1997).

The seawater temperature presents seasonal variations, usual in temperate latitudes, ranging from a mean of $19.6^{\circ} \mathrm{C}$ during summer to $15.5^{\circ} \mathrm{C}$ in the winter (Dolbeth et al. 2006).

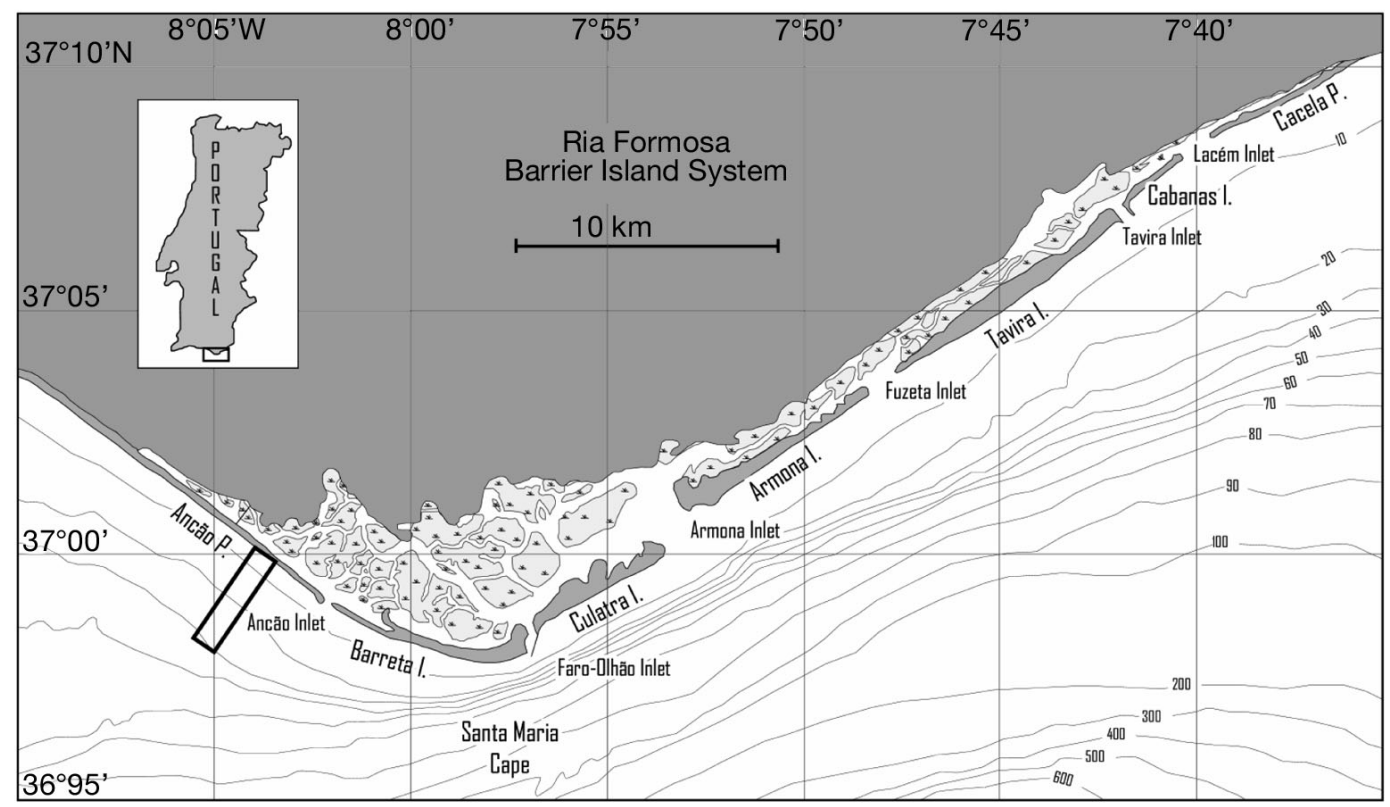

Fig. 1. Study area location (box) within the Ria Formosa barrier islands system. Depth contours in m 
Data acquisition and analysis. Wave climate: Offshore wave data for the study period was obtained from the Faro wave buoy, placed at the $93 \mathrm{~m}$ depth contour, in front of Cape Santa Maria. Measurements were taken every $3 \mathrm{~h}$ for the analysed period (June 2001 to October 2002), with very few missing data. For the purpose of this study, only $\mathrm{H}_{\mathrm{s}}$ was used. The number of storms $\left(\mathrm{H}_{\mathrm{s}}>3 \mathrm{~m}\right)$ and the absolute maximum $\mathrm{H}_{\mathrm{s}}\left(\mathrm{H}_{\text {smax }}\right)$ were identified for each period between consecutive biological samplings.

Morphological parameters: $\mathrm{D}_{\mathrm{c}}$ was determined by morphological comparison of repeated bathymetric surveys of 6 profiles, each separated by $20 \mathrm{~m}$ alongshore. A set of 84 profiles for 14 different survey periods was obtained from July 2001 to November 2003. For the purposes of this study, only 7 bathymetric surveys were analysed (July and September 2001, and February, May, June, July and October 2002). The bathymetric surveys chosen were those closest in time to the biological sampling. With the exception of the July 2001 survey, all surveys were obtained in the same month as the biological sampling, and in most cases within $15 \mathrm{~d}$, allowing a direct comparison between results. There were no storms or significant changes in the wave regime between benthic and bathymetric surveys. For the nearshore surveys we used a single point echosounder for water depth measurement, coupled with a real-time kinematic differential GPS (RTK-DGPS) for positioning and navigation software (HYPACK Max, Hypack). The measured depths were corrected for water level variation (i.e. tides and waves) using the heights recorded by the RTK-DGPS. The surveyed profile lines ended at approximately 18 to $20 \mathrm{~m}$ below mean sea level (MSL). This depth was much greater than expected, allowing $\mathrm{D}_{\mathrm{c}}$ determination. For the estimation of the overall vertical accuracy of the nearshore surveys, duplicate measurements of each profile were performed. Mean absolute difference between profiles was $16.5 \mathrm{~cm}$, therefore we defined $\mathrm{D}_{\mathrm{c}}$ as the depth beyond which the morphological changes were $<20 \mathrm{~cm}$. $\mathrm{D}_{\mathrm{c}}$ was then determined for consecutive surveys at each of the 6 profiles. An average value of the 6 profiles was then used as representative of $D_{c}$ for each analysed period. Based on the determined $D_{C}$, the average extension of the mixed profile $\left(E_{x}\right)$ was computed for each period analysed. This parameter represents the distance between the shoreline and the $\mathrm{D}_{\mathrm{c}}$ position in the profile, assuming the shoreline to be the contact between the MSL and the beach profile (on average about $70 \mathrm{~m}$ from the origin of the profile, the dune/beach contact). $E_{x}$ therefore gives the extension of the nearshore profile that was subjected to a mixing depth $\geq 20 \mathrm{~cm}$ for each period analysed.

Biological and sediment sampling: Sampling occurred along a depth gradient towards the eastern end of the Ancão Peninsula (Fig. 1), where the effect of the ebb delta of Ancão inlet was not felt. In this area, 14 sampling stations were defined along a perpendicular subtidaltransect, according to the distance from the shoreline $(100,200,300,400,500,600,800,1000,1400,1800,2400$, 3000, 4000, $5000 \mathrm{~m}$ offshore). Opportunistic surveys, strongly dependent on the wave conditions, were conducted between 2001 and 2002, totalling 7 sampling dates: June and September 2001, and February, May, June, July and October 2002. In June 2001 and February 2002, sampling could not be performed at the sampling station $5000 \mathrm{~m}$ offshore. Biological material was collected using a small dimension grab sampler (similar to Petit Ponar, $248 \mathrm{~cm}^{2}$ ). Each grab had an approximate minimum depth of penetration of $10 \mathrm{~cm}$. In all sampling stations, about 4 grab samples of biological material were collected (samples were washed through a $500 \mu \mathrm{m}$ mesh bag) and in June 2001, February 2002 and June 2002, one extra grab sample was also collected for sediment analysis (at each of the sampling points), totalling 383 samples of macrobenthic fauna and 40 sediment samples. The sediment samples were analyzed for grain size using the classical methods of sieving for the coarse grained material and classified according to Shepard (1954). It was assumed that sediment characteristics would represent the major changes within each 6 mo, and that the major changes would occur during the transitions between periods of lower (late spring, i.e. June) and higher (winter, i.e. February) hydrodynamics acting at the sea floor. In the laboratory, biological material was sorted, identified to the lowest possible taxon (in most cases species level) and counted.

Multivariate analysis of the macrofaunal assemblages: The structure of the macrobenthic community was investigated using multivariate techniques provided by PRIMER software (version 5.2.6, PRIMER-E). Similarity relationships of all biotic data results $(7$ sampling dates) were determined by the Bray-Curtis coefficient, after square-root-transformation of the raw data. A hierarchical cluster analysis (CLUSTER) was subsequently performed to identify similar faunal groups along the depth gradient. Non-metric multidimensional scaling (MDS) analysis was also performed to clarify and show the defined faunal groups, and afterwards these were classified in different depth ranges. For each depth range, a similarity percentages (SIMPER) analysis was used to determine the species that most contributed for the differences among depth ranges.

Simple linear regressions were used to identify variation patterns of species richness and density (dependent variables) with the physical parameters (independent variables), using STATISTICA software. Prior to the regression analysis, the normal distribution of the dependent population was assessed. 


\section{RESULTS}

\section{Wave climate}

During the study period a total of 8 storms were observed, 4 of them between September 2001 and February 2002 and 3 from February to May 2002 (Table 1). For both periods, the maximum observed significant offshore wave height reached at least $4 \mathrm{~m}$, and was almost $5 \mathrm{~m}$ for the period from October 2001 to February 2002. Such wave height has an estimated return period of about 5 yr (H. O. Pires unpubl. data) and is classified as a near extreme storm for the regional wave regime (moderate wave energy). A single storm of smaller wave en$\operatorname{ergy}\left(\mathrm{H}_{\mathrm{smax}}=3.3 \mathrm{~m}\right)$ and duration $(>3 \mathrm{~m}$ in only 1 measurement, representing a maximum of $3 \mathrm{~h}$ ) occurred in the period July to October 2002 (Table 1).

\section{Morphological parameters}

The observed $\mathrm{D}_{\mathrm{c}}$ for the study period (July 2001 to October 2002) ranged from approximately 2 to $10 \mathrm{~m}$ below MSL. The $\mathrm{D}_{\mathrm{c}}$ clearly demonstrated a variation through time in accordance with the wave energy distribution. Observed changes were minimal during low-energy periods and the maximum values were directly associated with high-energy (stormy) periods, with $\mathrm{H}_{\mathrm{s}} \geq 4 \mathrm{~m}$ (Table 1). During low-energy periods, $\mathrm{D}_{\mathrm{c}}$ was near the lower low tide level (about $2 \mathrm{~m}$ below MSL), indicating a small wave impact at the nearshore seafloor. For the most of the year, $D_{c}$ values were $<3.5 \mathrm{~m}$ below MSL and $\mathrm{E}_{\mathrm{x}}$ values were $<150 \mathrm{~m}$ (Table 1), meaning that the mixed profile was restricted to a small portion near the shoreline. The higher values of $\mathrm{D}_{\mathrm{c}}$ represent a complete mixing of the sediment cover up to $600 \mathrm{~m}$ from the shoreline. In these cases, the induced vertical changes reach 30 to $50 \mathrm{~cm}$ at a large portion of the mixed part of the profile. Maximum vertical changes of more than $1 \mathrm{~m}$ were observed for the period of September 2001 to February 2002.

Table 1. Number of storms (significant wave height $\mathrm{H}_{\mathrm{s}}>3 \mathrm{~m}$ ), maximum significant wave height $\left(\mathrm{H}_{\mathrm{smax}}\right)$, average depth of closure $\left(D_{c}\right)$, and average extension of the mixed profile $\left(E_{x}\right)$ for each analysed period

\begin{tabular}{|lcccc|}
\hline Period & Number of storms & $\begin{array}{c}\mathrm{H}_{\text {smax }} \\
(\mathrm{m})\end{array}$ & $\begin{array}{c}\mathrm{D}_{\mathrm{c}} \\
(\mathrm{m})\end{array}$ & $\begin{array}{c}\mathrm{E}_{\mathrm{x}} \\
(\mathrm{m})\end{array}$ \\
\hline Jul-Sep 01 & 0 & 1.95 & 3.5 & 140 \\
Sep 01-Feb 02 & 4 & 4.9 & 10.0 & 580 \\
Feb-May 02 & 3 & 4.0 & 6.6 & 350 \\
May-Jun 02 & 0 & 1.65 & 3.3 & 100 \\
Jun-Jul 02 & 0 & 1.3 & 2.3 & 60 \\
Jul-Oct 02 & 1 & 3.3 & 3.3 & 100 \\
\hline
\end{tabular}

\section{Sediment texture}

Sediment texture along the depth gradient presented a clear zonation with depth. Fine to very fine sands were observed near the shore down to $4 \mathrm{~m}$ depth in June 2001 and February 2002, extending down to 7 to $8 \mathrm{~m}$ depth in June 2002 (Fig. 2). In deeper areas, mainly deeper than 6 to $7 \mathrm{~m}$, there were coarser sands down to at least $20 \mathrm{~m}$ (Fig. 2). Relict sediments, composed by empty shells, coarse sands and gravel, appeared beyond $25 \mathrm{~m}$ depth. Fine sands were also detected in positions near rocky outcrops (detected at 25.6 m depth, February 2002, not shown in Fig. 2) and together with the relict sediments (sampling station 5000 m offshore, June 2002) (Fig. 2).

\section{Macrobenthic sub-littoral fauna}

Community structure, main species and sediment texture

A CLUSTER analysis was performed for all samples where the clustering samples were detected. From the clustering samples different groups were set, clarified and shown in the MDS analysis (I1, I2, II, III; Fig. 3). Accordingly, the community was spatially separated into 3 main groups, defined along the depth gradient (Fig. 3). Group I comprised the shallowest depths, from 1.3 to $7.2 \mathrm{~m}$ deep (sampling stations from 100 to $500 \mathrm{~m}$ offshore). Within this group, 2 sub-groups were discriminated: I1, from 1.3 to $3.4 \mathrm{~m}$ deep (sampling stations 100 and $200 \mathrm{~m}$ offshore) and I2, from 4.2 to $7.2 \mathrm{~m}$ deep (sampling stations 300 to $500 \mathrm{~m}$ offshore) (Fig. 3). Crustaceans were the most diverse and abundant group in the fine sands samples of Group I1, having Diogenes pugilator and Bathyporeia spp. as discriminating species (Table 2) and among the most abundant for all sampling dates (Table 3). Siphonoecetes sp. was also present, but mainly in the shallowest station (1.6 $\pm 0.33 \mathrm{~m}$ deep) and with exceptionally high density in July 2002 (at $2 \mathrm{~m}$ deep, 5927 ind. $\mathrm{m}^{-2}$ ). Group I2 was characterised by coarse sands in June 2001 and February 2002, and by fine to medium sands in June 2002 (Fig. 2). At these depths, molluscs and polychaetes attained higher densities (Table 2, Table 3). Among the most discriminating species were several surf-clams, polychaetes (such as Prionospio caspersi), echinoderms and again D. pugilator (Table 2).

Group II extended from 8.2 to $25.8 \mathrm{~m}$ deep, comprising the sampling stations from 600 to $4000 \mathrm{~m}$ offshore (Fig. 3). A high number of polychaetes appeared in this depth range, from which Pisione 


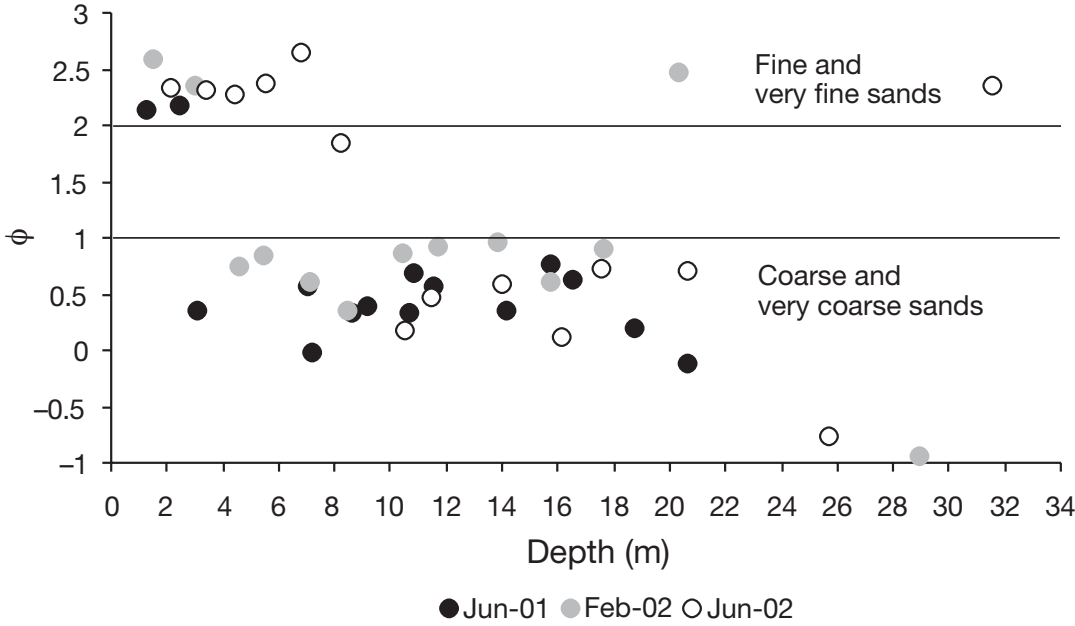

Fig. 2. Sediment texture (mean grain size, $\phi$ ) along the depth gradient. Classification: $\phi=-1$ to 0 : very coarse sands; $\phi=0$ to 1 : coarse sands; $\phi=1$ to 2: medium sands; $\phi=2$ to 3 : fine sands; $\phi=3$ to 4 : very fine sands

remota dominated (Table 2). Nematoda, Nemertea and the species Phascolion strombus (Sipuncula) and Branchiostoma lanceolatum (Hemichordata) were also present as discriminating taxa (Table 2) and occurred in higher abundances in this depth group (Table 3).

The sampling station $5000 \mathrm{~m}$ offshore (about $32 \mathrm{~m}$ deep) composed Group III (Fig. 3). Annelids were the most diverse and abundant group, yet the clam Calyptraea chinensis and the amphipod Harpinia antennaria seemed the most discriminating species (Table 2).

In terms of general patterns for the species number and density variation along the whole depth gradient, lower values were observed in the shallower depths (Fig. 4). The species number gradually increased down to $26 \mathrm{~m}$, where it attained the highest value (except in June 2001), decreasing after that (Fig. 4A). This increase with depth was verified by the positive slopes of the linear regression analysis, which were all significant, except for February 2002 (Table 4). Density increased considerably at 8 to $9 \mathrm{~m}$, attaining the highest value (Fig. 4B). Positive slopes were found for the depths $<9 \mathrm{~m}$, except for July 2002, which, although not significant, showed a decreasing tendency along the gradient (Table 4), due to the high densities of Siphonoecetes sp. observed in the shallowest depths. Beyond $10 \mathrm{~m}$, density seemed to gradually decrease with the depth (Fig. 4B), as seen from the generally negative slopes of the regression analysis (although only significant for February), except for June 2002, where an increasing pattern was seen (Table 4), also related to the general low densities observed for the month (Table 5).
Temporal differences

The MDS of the macrobenthic community showed no clear formation of subgroups with respect to temporal differences (different seasons, Fig. 3). Some of the most abundant species in each depth range were present throughout all sampling occasions, especially for the Groups I1, II and III (Table 3). The highest differences in the variation of the 5 most abundant species with season were found in Group I2, but these were not detected in the MDS plot (Fig. 3).

Regarding species richness and density, the highest values in the Group I community were obtained in June 2001. Afterwards, these values decreased, with the exception of density in July 2002 (Table 5), whose value was high due to Siphonoecetes sp. density. The former values of species richness obtained in June 2001, and even of density (if Siphonoecetes sp. density is ignored in July 2002), were never attained again. The minimum values were obtained in February and May 2002, and almost doubled in July and October 2002 (Table 5). Both species richness and density of the Group II community, from 8.4 to $25.8 \mathrm{~m}$ deep, were higher in June and September 2001 (late spring and late summer), decreasing to the lowest value in February 2002 (winter, Table 5, Fig. 4). In the spring (May and June) 2002, species richness and density started to increase again, but the range of values ob-

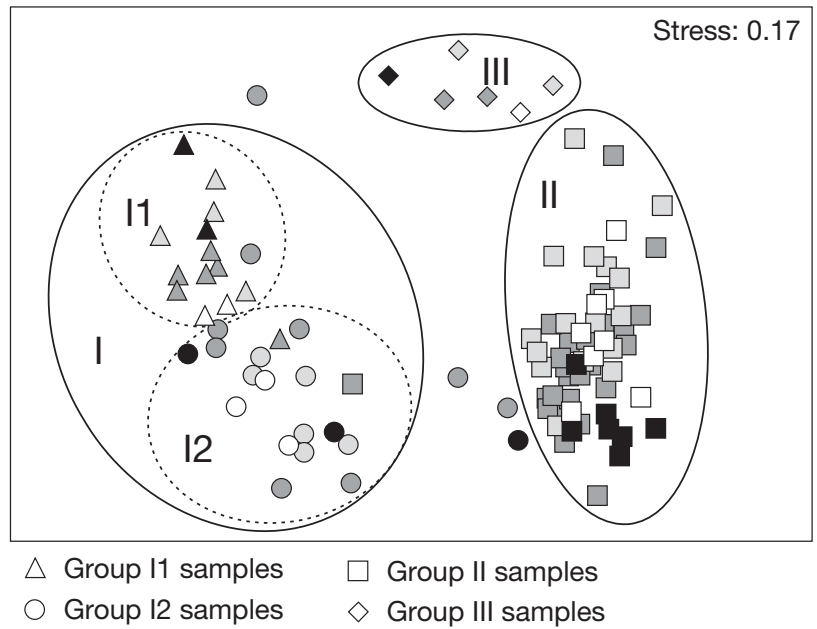

Fig. 3. MDS ordination plot of the macrobenthic communities. Spatial distribution of all communities for all study periods, with different symbols for each clustering group of samples. Groups I to III correspond to depth ranges (see Table 2). Dark grey symbols: spring (May, June); light grey symbols: summer (July, September); white symbols: autumn (October); black symbols: winter (February) 
Table 2. Mean (range) number of species and density (range) (N) of the main taxa for each depth range determined with the MDS, with indication of the depth, sediment characteristics and similarity of each group for characteristic species defined by SIMPER analysis. 'Others' constituted by Phascolion strombus (Sipuncula), Branchiostoma lanceolatum (Hemichordata) and the groups Nemertea and Nematoda (from which species were not identified)

\begin{tabular}{|c|c|c|c|c|c|}
\hline $\begin{array}{l}\text { MDS group } \\
\text { (depth range) }\end{array}$ & Characterisation & Main taxa & No. of species & $\mathrm{N}$ (ind. $\mathrm{m}^{-2}$ ) & $\begin{array}{c}\text { Characteristic } \\
\text { species }\end{array}$ \\
\hline I1 $(1.3-3.4 \mathrm{~m})$ & $\begin{array}{l}\text { Fine sands. } \\
\text { Average group } \\
\text { similarity of } 37 \%\end{array}$ & $\begin{array}{l}\text { Annelida } \\
\text { Crustacea } \\
\text { Mollusca } \\
\text { Echinodermata } \\
\text { Others }\end{array}$ & $\begin{aligned} 4 & (1-8) \\
10 & (4-21) \\
4 & (1-9) \\
2 & (1-3) \\
& -\end{aligned}$ & $\begin{array}{c}67(5-130) \\
943(297-2094) \\
110(5-494) \\
45(5-135) \\
11(0-26)\end{array}$ & $\begin{array}{l}\text { Diogenes pugilator, } \\
\text { Bathyporeia spp., } \\
\text { Siphonoecetes sp., }\end{array}$ \\
\hline I2 $(4.2-7.1 \mathrm{~m})$ & $\begin{array}{l}\text { Fine and } \\
\text { coarse sands. } \\
\text { Average group } \\
\text { similarity of } 27 \%\end{array}$ & $\begin{array}{l}\text { Annelida } \\
\text { Crustacea } \\
\text { Mollusca } \\
\text { Echinodermata } \\
\text { Others }\end{array}$ & $\begin{array}{c}17(8-36) \\
17(10-33) \\
17(10-26) \\
2(1-3) \\
-\end{array}$ & $\begin{array}{c}740(118-2339) \\
338(74-576) \\
1032(63-2024) \\
136(14-306) \\
138(0-576)\end{array}$ & $\begin{array}{l}\text { Tellina spp., } \\
\text { Diogenes pugilator, } \\
\text { Prionospio caspersi, } \\
\text { Spisula solida, } \\
\text { Nephtys cirrosa, } \\
\text { Ophiocentrus branchiatus, } \\
\text { Donax sp., } \\
\text { Magelona papillicornis, }\end{array}$ \\
\hline II $(8.2-25.8 \mathrm{~m})$ & $\begin{array}{l}\text { Coarse sands; } \\
\text { relict sediments } \\
\text { at } 25.7 \pm 0.12 \mathrm{~m} \text {. } \\
\text { Average group } \\
\text { similarity of } 30 \%\end{array}$ & $\begin{array}{l}\text { Annelida } \\
\text { Crustacea } \\
\text { Mollusca } \\
\text { Echinodermata } \\
\text { Others }\end{array}$ & $\begin{array}{c}67(31-82) \\
55(16-83) \\
34(15-43) \\
4(2-6) \\
-\end{array}$ & $\begin{array}{c}1455(400-2419) \\
366(50-861) \\
322(174-561) \\
40(3-99) \\
1034(242-1903)\end{array}$ & $\begin{array}{l}\text { Nematoda, } \\
\text { Pisione remota, } \\
\text { Phascolion strombus, } \\
\text { Nemertea, } \\
\text { Branchyostoma lanceolatum, } \\
\text { Caulleriella bioculata, } \\
\text { Goniada galaica, } \\
\text { Caecum sp., }\end{array}$ \\
\hline III $(31.8 \pm 0.2 \mathrm{~m})$ & $\begin{array}{l}\text { Fine sands with } \\
\text { mud deposits. } \\
\text { Average group } \\
\text { similarity of } 27 \%\end{array}$ & $\begin{array}{l}\text { Annelida } \\
\text { Crustacea } \\
\text { Mollusca } \\
\text { Others } \\
\text { Echinodermata }\end{array}$ & $\begin{array}{c}21(7-31) \\
13(4-22) \\
10(3-18) \\
- \\
1(0-2)\end{array}$ & $\begin{array}{c}864(111-2125) \\
379(56-764) \\
386(56-854) \\
45(0-126) \\
30(0-73)\end{array}$ & $\begin{array}{l}\text { Calyptraea chinensis, } \\
\text { Harpinia antennaria, } \\
\text { Magelona rosea, } \\
\text { Corbulla gibba, } \\
\text { Lumbriconereis gracilis, } \\
\text { Prionospio cirrifera, } \\
\text { Ampelisca tenuicornis, } \\
\text { Ampelisca spinimana }\end{array}$ \\
\hline
\end{tabular}

tained in June 2001 was only obtained in July 2002 (summer) (Table 5). This was even more evident for the density, which only reached similar values in October 2002 (autumn) (Table 5). When analysing the calm depths of $31.8 \mathrm{~m}$ alone, the highest values were found in June 2002 (Table 5), mainly due to the expressive occurrence of polychaetes at those depths.

The variation of species number along the depth gradient for the main seasons showed an increase at $6 \mathrm{~m}$ depth for June 2001, while for the other seasons this increase occurred deeper (Fig. 4A). Density values started to increase around $8 \mathrm{~m}$ deep in June 2001, September 2002 and October 2002, while in February and June 2002 this increase was quite slender (Fig. 4B).

\section{Physical and biological interactions}

According to the morphological parameters, active depths within the gradient show seasonal variations, with maximum values of $D_{c}$ and $E_{x}$ obtained in Sep- tember 2001 to February 2002 (Table 1). On the other hand, the spatial separation of the macrobenthic communities groups suggest that Group I, in the shallower depths, may be representative of these active depths, meaning that its community will be subjected to some hydrodynamic impact, according to the season. The depth range of Group I did not include the maximum observed values of $D_{c}$ and $E_{x}$ at $10 \mathrm{~m}$ depth and $600 \mathrm{~m}$ offshore. The sampling station nearest the $10 \mathrm{~m}$ depth was always associated with the Group II community (Fig. 3), representative of calm depths, with no hydrodynamic impact. This is also consistent with the sediment texture zonation, where beyond the $8 \mathrm{~m}$ depth there were always coarse sands (Fig. 2). Accordingly, the maximal active depth profile was considered to correspond only to the Group I depth range, namely from 1.3 to $7.2 \mathrm{~m}$ deep.

The regression analysis between the biological (species number and density) and physical parameters (wave climate and morphological parameters) showed generally negative relations (Fig. 5). Regressions were 
only statistically significant for the species number and the slopes of the regression were steeper for the calm depths, showing higher decreases (Fig. 5). For density, these negative regressions were only observed for the active depths, but were not statistically significant (Fig. 5). From the species number and density variation along the gradient (Fig. 4), it is also clear that the extension of the lowest species number and density varied in accordance with the seasons of higher energy periods (Table 1). So, for February and June 2002, which followed high energy periods with a larger $E_{x}$ (Table 1), the increase of both species number and density was quite small when compared to the other months (Fig. 4).

\section{DISCUSSION}

\section{Macrobenthic community spatial patterns}

Depth seemed to exert a strong influence on the spatial distribution and composition of the benthic macrofauna, as clear spatial differences were found along the depth gradient. Similar changes in the sublittoral macrofaunal communities distribution with depth were related to changes in the food supply and quality, water stability, and reduction of the physical disturbance (such as storm, wind influence) (Morin et al. 1985, Rosenberg 1995, Snelgrove 1998, HernándezArana et al. 2003). In the present study, at least 3 spa-

Table 3. Most abundant taxa at each sampling date (mo/yr) for each depth range determined with MDS

\begin{tabular}{|c|c|c|c|c|}
\hline \multirow{2}{*}{$\begin{array}{l}\text { Sampling } \\
\text { date }\end{array}$} & \multirow[b]{2}{*}{$\mathrm{I} 1$ (1.3 to $3.4 \mathrm{~m})$} & \multicolumn{2}{|c|}{ Group (depth range) } & \multirow[b]{2}{*}{ III $(31.8 \pm 0.2 \mathrm{~m})$} \\
\hline & & I2 $(4.2$ to $7.1 \mathrm{~m})$ & II (8.2 to $25.8 \mathrm{~m})$ & \\
\hline Jun 01 & $\begin{array}{l}\text { 1. Bathyporeia spp. } \\
\text { 2. Diogenes pugilator } \\
\text { 3. Donax sp. } \\
\text { 4. Spio sp. } \\
\text { 5. Prionospio caspersi }\end{array}$ & $\begin{array}{l}\text { 1. Pisione remota } \\
\text { 2. Saccocirrus papillocercus } \\
\text { 3. Spisula solida } \\
\text { 4. Goniada galaica } \\
\text { 5. Nematoda }\end{array}$ & $\begin{array}{l}\text { 1. Nematoda } \\
\text { 2. Pisione remota } \\
\text { 3. Nemertea } \\
\text { 4. Phascolion strombus } \\
\text { 5. Goniada galaica }\end{array}$ & Not sampled \\
\hline Sep 01 & $\begin{array}{l}\text { 1. Bathyporeia spp. } \\
\text { 2. Siphonoecetes sp. } \\
\text { 3. Diogenes pugilator } \\
\text { 4. Ophiuroidea n. id. } \\
\text { 5. Eocuma dollfusi }\end{array}$ & $\begin{array}{l}\text { 1. Tellina spp. } \\
\text { 2. Diogenes pugilator } \\
\text { 3. Prionospio caspersi } \\
\text { 4. Mysella bidentata } \\
\text { 5. Ophiocentrus branchiatus }\end{array}$ & $\begin{array}{l}\text { 1. Nematoda } \\
\text { 2. Pisione remota } \\
\text { 3. Caulleriella bioculata } \\
\text { 4. Nemertea } \\
\text { 5. Branchyostoma } \\
\text { lanceolatum }\end{array}$ & $\begin{array}{l}\text { 1. Corbulla gibba } \\
\text { 2. Turritella sp. } \\
\text { 3. Calyptraea chinensis } \\
\text { 4. Harpinia antennaria } \\
\text { 5. Chamalea gallina }\end{array}$ \\
\hline Feb 02 & $\begin{array}{l}\text { 1. Siphonoecetes sp. } \\
\text { 2. Diogenes pugilator } \\
\text { 3. Bathyporeia spp. } \\
\text { 4. Eocuma dollfusi }\end{array}$ & $\begin{array}{l}\text { 1. Pisione remota } \\
\text { 2. Nematoda } \\
\text { 3. Saccocirrus papillocercus } \\
\text { 4. Spisula solida } \\
\text { 5. Goniada galaica }\end{array}$ & $\begin{array}{l}\text { 1. Nematoda } \\
\text { 2. Pisione remota } \\
\text { 3. Caulleriella bioculata } \\
\text { 4. Nemertea } \\
\text { 5. Spisula solida }\end{array}$ & $\begin{array}{l}\text { 1. Phascolion strombus } \\
\text { 2. Flabelligeridae } \mathrm{n} \text {. id. } \\
\text { 3. Echinidae } \mathrm{n} \text {. id. } \\
\text { (sampled at } 29 \mathrm{~m} \text { deep) }\end{array}$ \\
\hline May 02 & $\begin{array}{l}\text { 1. Diogenes pugilator } \\
\text { 2. Bathyporeia spp. } \\
\text { 3. Nematoda } \\
\text { 4. Prionospio caspersi } \\
\text { 5. Ophiura ophiura }\end{array}$ & $\begin{array}{l}\text { 1. Diogenes pugilator } \\
\text { 2. Prionospio sp. } \\
\text { 3. Ophiuroidea } \mathrm{n} \text {. id. } \\
\text { 4. Mystides elongata } \\
\text { 5. Nematoda }\end{array}$ & $\begin{array}{l}\text { 1. Pisione remota } \\
\text { 2. Nematoda } \\
\text { 3. Goniada galaica } \\
\text { 4. Phascolion strombus } \\
\text { 5. Spisula solida }\end{array}$ & $\begin{array}{l}\text { 1. Harpinia antennaria } \\
\text { 2. Calyptraea chinensis } \\
\text { 3. Nematoda }\end{array}$ \\
\hline Jun 02 & $\begin{array}{l}\text { 1. Diogenes pugilator } \\
\text { 2. Bathyporeia spp. } \\
\text { 3. Prionospio caspersi } \\
\text { 4. Ophiocentrus } \\
\text { branchiatus } \\
\text { 5. Eocuma dollfusi }\end{array}$ & $\begin{array}{l}\text { 1. Ophiocentrus branchiatus } \\
\text { 2. Diogenes pugilator } \\
\text { 3. Magelona rosea } \\
\text { 4. Spisula solida } \\
\text { 5. Corbulla gibba }\end{array}$ & $\begin{array}{l}\text { 1. Pisione remota } \\
\text { 2. Nematoda } \\
\text { 3. Spisula solida } \\
\text { 4. Goniada galaica } \\
\text { 5. Phascolion strombus }\end{array}$ & $\begin{array}{l}\text { 1. Prionospio malmgreni } \\
\text { 2. Corbulla gibba } \\
\text { 3. Myxicola infundibulum } \\
\text { 4. Ampharete sp. } \\
\text { 5. Harpinia antennaria }\end{array}$ \\
\hline Jul 02 & $\begin{array}{l}\text { 1. Siphonoecetes sp } \\
\text { 2. Diogenes pugilator } \\
\text { 3. Bathyporeia spp. } \\
\text { 4. Atelecyclus } \\
\text { undecimdentatus } \\
\text { 5. Ophiuroidea n. id. }\end{array}$ & $\begin{array}{l}\text { 1. Tellina spp. } \\
\text { 2. Ophiuroidea n. id. } \\
\text { 3. Spisula solida } \\
\text { 4. Diogenes pugilator } \\
\text { 5. Prionospio caspersi }\end{array}$ & $\begin{array}{l}\text { 1. Nematoda } \\
\text { 2. Phascolion strombus } \\
\text { 3. Pisione remota } \\
\text { 4. Branchyostoma } \\
\text { lanceolatum } \\
\text { 5. Caecum imperforatum }\end{array}$ & $\begin{array}{l}\text { 1. Calyptraea chinensis } \\
\text { 2. Ampelisca spinimana } \\
\text { 3. Owenia fusiformis } \\
\text { 4. Ampharete sp. } \\
\text { 5. Prionospio cirrifera }\end{array}$ \\
\hline Oct 02 & $\begin{array}{l}\text { 1. Diogenes pugilator } \\
\text { 2. Bathyporeia spp. } \\
\text { 3. Tellina spp. } \\
\text { 4. Prionospio caspersi } \\
\text { 5. Ophiocentrus } \\
\text { branchiatus }\end{array}$ & $\begin{array}{l}\text { 1. Tellina tenuis } \\
\text { 2. Diogenes pugilator } \\
\text { 3. Prionospio caspersi } \\
\text { 4. Ophiocentrus branchiatus } \\
\text { 5. Mysella bidentata }\end{array}$ & $\begin{array}{l}\text { 1. Nematoda } \\
\text { 2. Pisione remota } \\
\text { 3. Branchyostoma } \\
\text { lanceolatum } \\
\text { 4. Goniada galaica } \\
\text { 5. Phascolion strombus }\end{array}$ & $\begin{array}{l}\text { 1. Magelona rosea } \\
\text { 2. Ampharete sp. } \\
\text { 3. Harpinia antennaria } \\
\text { 4. Prionospio sp. } \\
\text { 5. Ampelisca typica }\end{array}$ \\
\hline
\end{tabular}



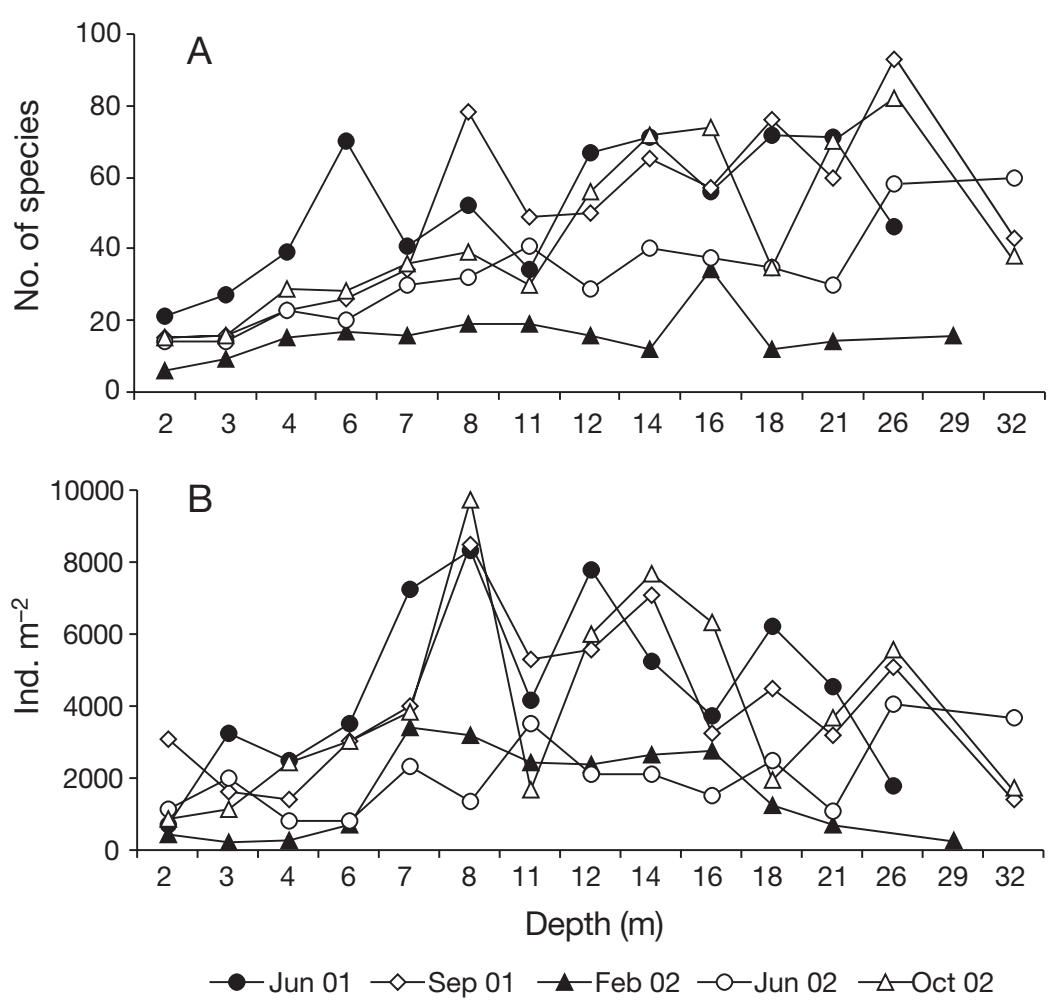

Fig. 4. Variation in the macrobenthic community. (A) Species number and (B) density along the depth gradient for the main seasons. Late spring: June 2001, June 2002; late summer: September 2001; winter: February 2002; autumn: October 2002

tial groups were discriminated, corresponding to areas of high and low hydrodynamic impact, similar to the zonation patterns found at Zuma Beach, California (Morin et al. 1985) and Masnou Beach, Spain (Munilla \& Vicente 2005) for the subtidal communities along a depth gradient. Occupying more hydrodynamic areas
(1.3 to $3.4 \mathrm{~m}$ depth), composed by fine to medium sands, were some crustaceans adapted to environmental stress (such as the hermit crabs), which agrees with other surf zone studies (Vicente \& Sorbe 1999, Beyst et al. 2001a, Connor et al. 2004, Janssen \& Mulder 2005). These depths presented the lowest species number and density, which was also reported by Morin et al. (1985), Jansen \& Mulder (2005) and Munilla \& Vicente (2005) at the shallow, more hydrodynamic areas down to $7 \mathrm{~m}$ depth, beyond which the species richness increased (water depths shallower than $30 \mathrm{~m}$ ). Bivalves followed in the gradient, as also seen by Hoey et al. (2004). Potentially still within the $\mathrm{D}_{\mathrm{c}}$ range (4.2 to $7.2 \mathrm{~m}$ deep), the surf clams were quite abundant, including Spisula solida and Donax sp., commercially harvested on the Portuguese south coast (Gaspar et al. 1999, Chícharo et al. 2002, Dolbeth et al. 2006).

Following the depth gradient, mainly below the $D_{c}$ and seaward of the $E_{x}$ (coarser sands), was a diverse polychaete community, along with nematodes, sipunculids and amphioxus. This depth range, from 8.4 to $25.8 \mathrm{~m}$, had the highest diversity and abundance of individuals. Other studies between 8 and $18 \mathrm{~m}$ deep reported similar key taxa, the polychaete community being the most diverse and abundant (Sardá et al. 1999, Wieking \& Kröncke 2003, Hoey et al. 2004). At the beginning of this depth range, at $8.4 \mathrm{~m}$, density increased substantially, but gradually decreased afterwards. The physical disturbance at $7 \mathrm{~m}$ shorewards might have forced

Table 4. Simple linear regression equations, coefficients and statistical significance $\left({ }^{*} \mathrm{p}<0.05\right.$; ns: not significant) of the relationships between depth (D) and number of species $(\mathrm{S})$ and density $\left(\mathrm{N}\right.$, ind. $\mathrm{m}^{-2}$ ), for different sections of the gradient

\begin{tabular}{|c|c|c|c|}
\hline \multirow{2}{*}{ Sampling date (mo/yr) } & \multirow{2}{*}{$\begin{array}{l}\text { No. of species } \\
1 \text { to } 26 \mathrm{~m} \text { deep }\end{array}$} & \multirow{2}{*}{\multicolumn{2}{|c|}{1 to $9 \mathrm{~m}$ deep $\quad$ Density 10 to $33 \mathrm{~m}$ deep }} \\
\hline & & & \\
\hline \multirow[t]{2}{*}{ Jun 01} & $\mathrm{~S}=1.3926 \mathrm{D}+35.665$ & $\mathrm{~N}=844.36 \mathrm{D}+66.084$ & $\mathrm{~N}=-228.17 \mathrm{D}+8565.3$ \\
\hline & $\mathrm{R}^{2}=0.32 ; \mathrm{p}=0.042^{*}$ & $\mathrm{R}^{2}=0.77 ; \mathrm{p}=0.021^{*}$ & $\mathrm{R}^{2}=0.40 ; \mathrm{p}=0.126^{\mathrm{ns}}$ \\
\hline \multirow[t]{2}{*}{ Sep 01} & $\mathrm{~S}=2.9784 \mathrm{D}+15.845$ & $\mathrm{~N}=706.25 \mathrm{D}+58.127$ & $\mathrm{~N}=-167.04 \mathrm{D}+7516.1$ \\
\hline & $\mathrm{R}^{2}=0.74 ; \mathrm{p}=0.0002^{*}$ & $\mathrm{R}^{2}=0.55 ; \mathrm{p}=0.093^{\mathrm{ns}}$ & $\mathrm{R}^{2}=0.48 ; \mathrm{p}=0.057 \mathrm{~ns}$ \\
\hline \multirow[t]{2}{*}{ Feb 02} & $\mathrm{~S}=0.2369 \mathrm{D}+13.06$ & $\mathrm{~N}=495.77 \mathrm{D}-1113.7$ & $\mathrm{~N}=-139.9 \mathrm{D}+4149.8$ \\
\hline & $\mathrm{R}^{2}=0.078 ; \mathrm{p}=0.356^{\mathrm{ns}}$ & $\mathrm{R}^{2}=0.72 ; \mathrm{p}=0.034^{*}$ & $\mathrm{R}^{2}=0.75 ; \mathrm{p}=0.012^{*}$ \\
\hline \multirow[t]{2}{*}{ May 02} & $\mathrm{~S}=1.6349 \mathrm{D}+6.0361$ & $\mathrm{~N}=284.85 \mathrm{D}-355.77$ & $N=-90.103 D+3847$ \\
\hline & $\mathrm{R}^{2}=0.694 ; \mathrm{p}=0.0004^{*}$ & $\mathrm{R}^{2}=0.38 ; \mathrm{p}=0.192^{\mathrm{ns}}$ & $\mathrm{R}^{2}=0.41 ; \mathrm{p}=0.086^{\mathrm{ns}}$ \\
\hline \multirow[t]{2}{*}{ Jun 02} & $\mathrm{~S}=1.3887 \mathrm{D}+15.401$ & \multirow{2}{*}{\multicolumn{2}{|c|}{$\begin{array}{l}\text { Entire gradient: } \mathrm{N}=76.297 \mathrm{D}+1100.4 \\
\mathrm{R}^{2}=0.40 ; \mathrm{p}=0.016^{*}\end{array}$}} \\
\hline & $\mathrm{R}^{2}=0.673 ; \mathrm{p}=0.0005^{*}$ & & \\
\hline Jul 02 & $\mathrm{~S}=1.1971 \mathrm{D}+20.168$ & \multirow{2}{*}{\multicolumn{2}{|c|}{$\begin{array}{l}\text { Entire gradient: } \mathrm{N}=-78.638 \mathrm{D}+3086.9 \\
\qquad \mathrm{R}^{2}=0.19 ; \mathrm{p}=0.121^{\mathrm{ns}}\end{array}$}} \\
\hline & $\mathrm{R}^{2}=0.374 ; \mathrm{p}=0.026^{*}$ & & \\
\hline \multirow[t]{2}{*}{ Oct 02} & $\mathrm{~S}=2.7622 \mathrm{D}+14.045$ & $\mathrm{~N}=1153.4 \mathrm{D}-2319.9$ & $\mathrm{~N}=-200.42 \mathrm{D}+8589.2$ \\
\hline & $\mathrm{R}^{2}=0.74 ; \mathrm{p}=0.0002^{*}$ & $\mathrm{R}^{2}=0.76 ; \mathrm{p}=0.024^{*}$ & $\mathrm{R}^{2}=0.39 ; \mathrm{p}=0.136^{\mathrm{ns}}$ \\
\hline
\end{tabular}


Table 5. Number of species and densities for the active (I: 1.3 to $7.2 \mathrm{~m}$ depth) and calm depths (II: 8.4 to $25.8 \mathrm{~m}$ depth; III: $31.8 \pm$ $0.2 \mathrm{~m}$ ), and for the entire depth gradient. Groups Nematoda and Nemertea were not included in the number of species

\begin{tabular}{|c|c|c|c|c|c|}
\hline $\begin{array}{l}\text { Sampling date } \\
\text { (mo/yr) }\end{array}$ & & $\begin{array}{c}\text { Active depths } \\
(1.3 \text { to } 7.2 \mathrm{~m})\end{array}$ & $\begin{array}{l}\text { Calm depths } \\
\text { (8.2 to } 25.8 \mathrm{~m})\end{array}$ & $\begin{array}{l}\text { Calm depths } \\
(31.8 \pm 0.2 \mathrm{~m})\end{array}$ & $\begin{array}{l}\text { Entire gradient } \\
(1.3 \text { to } 32 \mathrm{~m})\end{array}$ \\
\hline \multirow[t]{2}{*}{ Jun 01} & No. of species & 106 & 192 & - & 221 \\
\hline & Ind. $\mathrm{m}^{-2}$ & 3428 & 5336 & - & 4655 \\
\hline \multirow[t]{2}{*}{ Sep 01} & No. of species & 64 & 194 & 41 & 223 \\
\hline & Ind. $\mathrm{m}^{-2}$ & 2606 & 5286 & 1417 & 4071 \\
\hline \multirow[t]{2}{*}{ Feb 02} & No. of species & 33 & 62 & $16^{\mathrm{a}}$ & 84 \\
\hline & Ind. $\mathrm{m}^{-2}$ & 996 & 1918 & $292^{\mathrm{a}}$ & 1588 \\
\hline \multirow[t]{2}{*}{ May 02} & No. of species & 37 & 115 & 38 & 151 \\
\hline & Ind. $\mathrm{m}^{-2}$ & 602 & 2520 & 698 & 1709 \\
\hline \multirow[t]{2}{*}{ Jun 02} & No. of species & 55 & 169 & 62 & 185 \\
\hline & Ind. $\mathrm{m}^{-2}$ & 1415 & 2100 & 3653 & 1999 \\
\hline \multirow[t]{2}{*}{ Jul 02} & No. of species & 63 & 156 & 54 & 201 \\
\hline & Ind. $\mathrm{m}^{-2}$ & $3103\left(1917^{b}\right)$ & 1452 & 1656 & 2088 \\
\hline \multirow[t]{2}{*}{ Oct 02} & No. of species & 55 & 180 & 37 & 216 \\
\hline & Ind. $\mathrm{m}^{-2}$ & 2250 & 5327 & 1708 & 3974 \\
\hline \multicolumn{6}{|c|}{ aSampled at $29 \mathrm{~m}$} \\
\hline
\end{tabular}

organisms to divert more energy towards maintenance, resulting in lower abundances. Yet, with the lower bottom disturbance at 8 to $9 \mathrm{~m}$, coupled with the relatively shallow depth (higher light penetration), potentially allowing higher food availability, density increased considerably. Seaward of this depth, density decreased, which may be related to a decrease in food quality and supply (Morin et al. 1985). At the $25.8 \mathrm{~m}$ depth alone, sediment was composed by relict deposits. This area is characterised by low hydrodynamics, from which the relict sediments are not in equilibrium with the low-energy conditions, as they consist of particles supplied to the shelf before the present time and under different hydrodynamic conditions. The community maintained some of its key species, being dominated by $P$. strombus (Sipuncula) and Nematoda and Nemertea groups. The deepest sampling station was composed of typical shelf deposits, with fine sands and mud deposits, also evidencing low hydrodynamics. The community at this area was more heterogenic, with no clear dominance of species. Amphipods, bivalves and polychaetes were a regular presence. At these depths, after the relict sediments, diversity and density showed a considerable decrease, probably due to the decreased of food availability (Morin et al. 1985).

\section{Physical and biological coupling}

The present study showed that the harsher the environment becomes in terms of the differences in wave climate impact, the lower the species number and density within the community. This was both spatially and temporally consistent. In fact, both wave climate and morphological parameters showed negative relationships with the biological parameters analysed, meaning that the higher the energy to which the community is subjected, the lower the species number and density in the inhabited area. This relation was more powerful for the species number than the density, and the decrease was more accentuated for the calm depths than for active depths. The active depths were determined by the benthic spatial distribution limit at $500 \mathrm{~m}$ offshore distance, $7.2 \mathrm{~m}$ deep, and because it was located within the $D_{c}$ range. These depths are potentially subjected to higher and continuous impact. Yet, according to the morphological data, the maximum active profile could extend up to $580 \mathrm{~m}$ offshore and $10 \mathrm{~m}$ depth (following extreme storm periods), which includes the calm depth range. So, when the wave impact in the sea bottom extends to the deeper areas usually not subjected to physical disturbance, the decrease in the number of species may be even more accentuated, as seen by the higher decrease in the species number for the calm depths. Also, during higher $\mathrm{D}_{\mathrm{c}}$ periods some species might distribute further offshore, as seen for Spisula solida (Dolbeth et al. 2006).

For the species density, the decrease was not significant, suggesting that while species richness would be directly affected by the physical environment, for density other factors might also have some impact, as suggested by Morin et al. (1985). This was evident for the calm depths, as during most of the year, these communities are not subjected to the highly hydrodynamic impact, being placed in more stable sediments with higher organic content allowing the settlement of a large amount of fauna (Incera et al. 2003). As a consequence, other factors that potentially may affect the species 
A

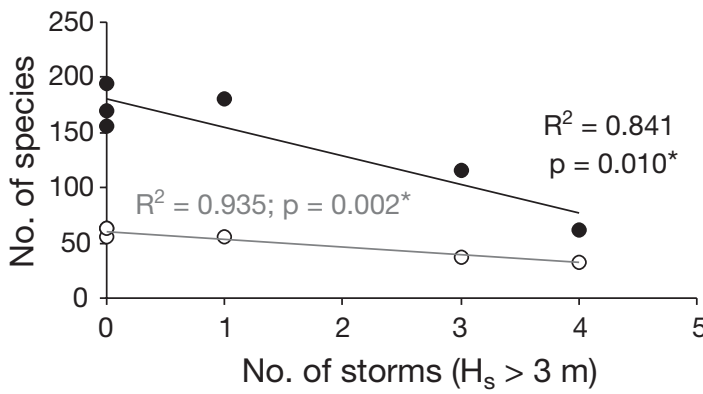

B

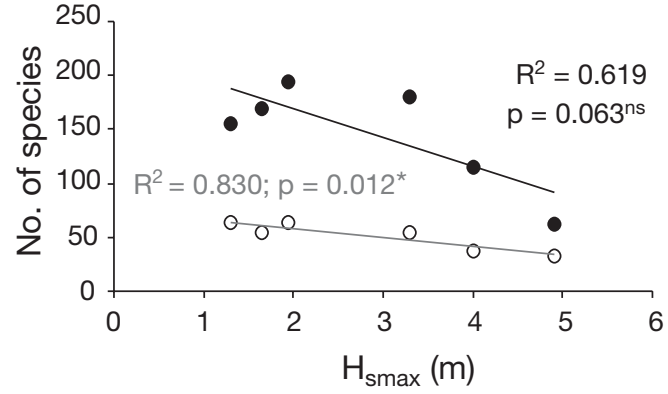

C

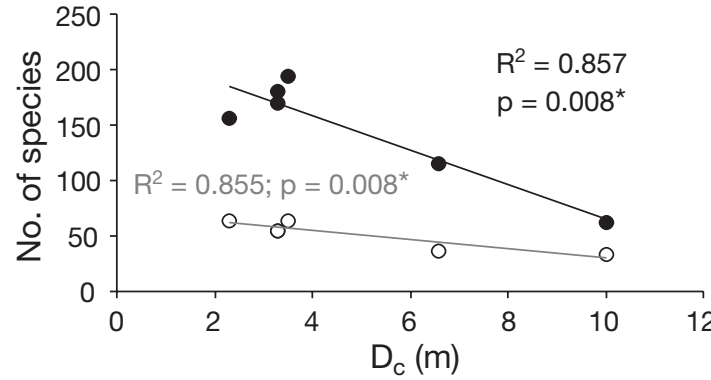

D

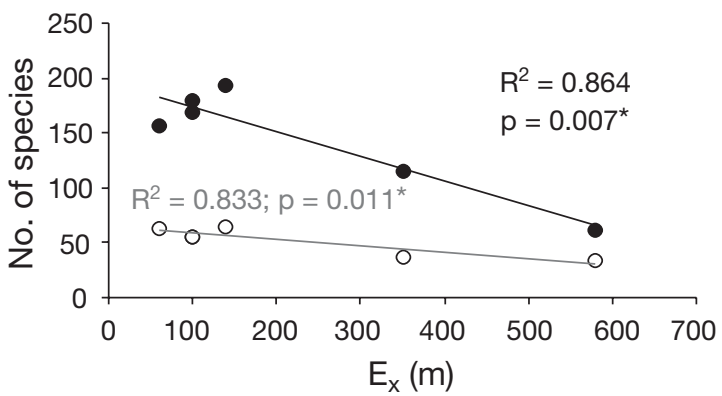

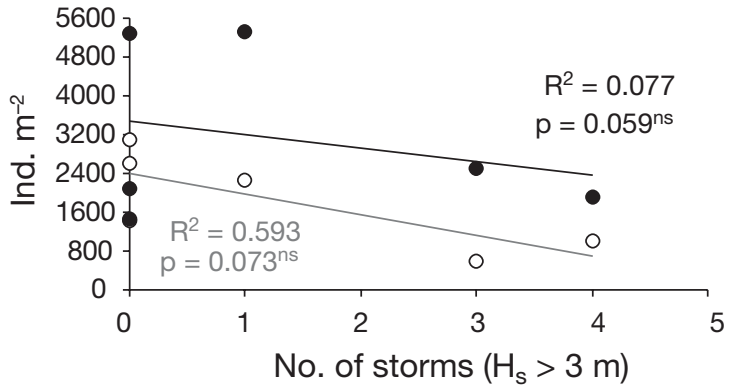
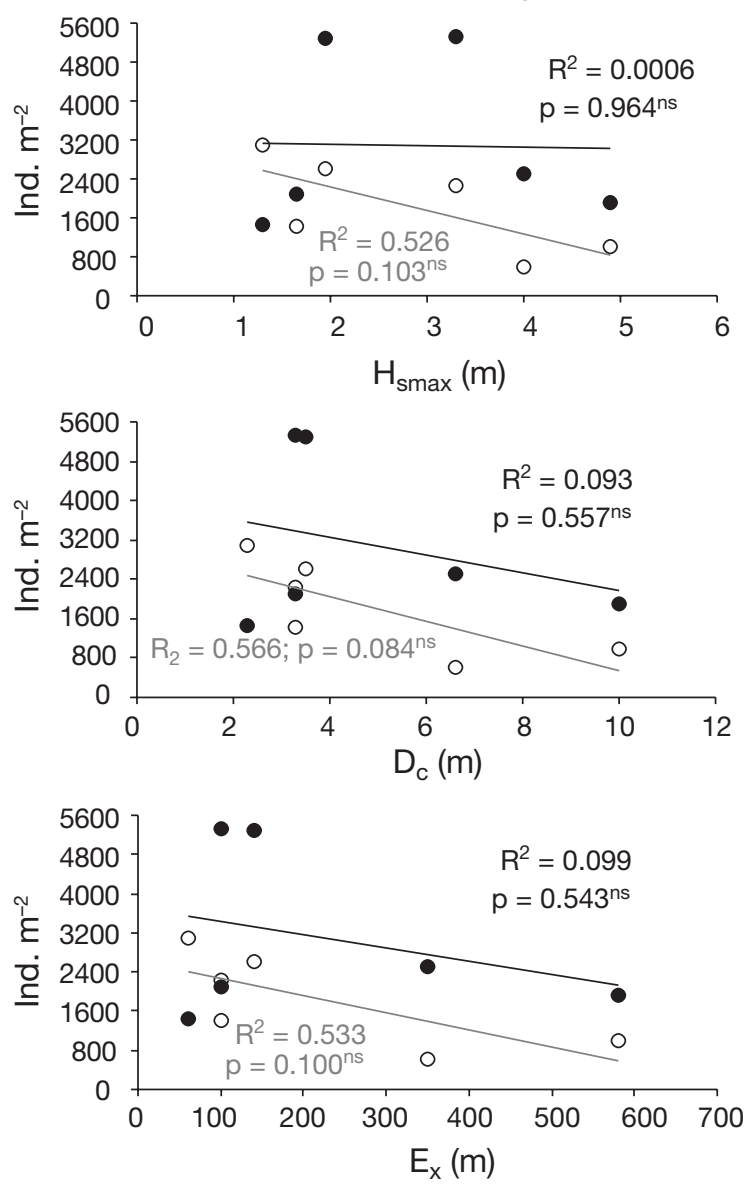

Fig. 5. Variation of macrobenthic community species quantity (left column) and density (right column) with (A) number of storms (i.e. wave height $\left.H_{s}>3 \mathrm{~m}\right)$, (B) maximum wave heights $\left(\mathrm{H}_{\mathrm{smax}}\right),(\mathrm{C})$ depth of closure $\left(\mathrm{D}_{\mathrm{c}}\right)$, (D) extension of the mixed profile $\left(\mathrm{E}_{\mathrm{x}}\right)$, along different sampling periods, with indication of the determination coefficient and statistical significance of the linear regression between each parameter ( ${ }^{*} \mathrm{p}<0.05$; ns: not significant). O: active depths (sampling stations 100 to $500 \mathrm{~m}$ offshore);

๑: calm depths (sampling stations 600 to $4000 \mathrm{~m}$ offshore)

dynamics and reproduction gain importance, such as the life cycle characteristics, recruitment success, biotic interactions, food availability, water temperature (Morin et al. 1985, Snelgrove 1998, Lastra et al. 2006) and potentially also anthropogenic impacts, due to clam fishery as seen by Dolbeth et al. (2006).

A comparable pattern of decreasing species richness along a morphodynamic gradient has been documented for intertidal beach assemblages, from reflec- tive to dissipative beaches (Brazeiro 2001, Rodil \& Lastra 2004, McLachlan \& Dorvlo 2005, Lastra et al. 2006, Rodil et al. 2006). This pattern is spatially and temporally consistent and it has been suggested that the reducing number of species would be associated with the environmental severity caused by swash climate, sediment dynamics, and erosion/accretion dynamics, all interacting with the biological processes (Brazeiro 2001). A similar pattern, also spatially and 
temporally consistent, seems to occur along a sublittoral depth gradient, from the high energy to the low energy depths. However, the environmental severity conditioning the fauna is determined by other physical variables, which may vary with season, and where the beach type may not have a strong impact. Among physical factors, the importance of sea bottom physical disturbance extension, which in turn influences other parameters such as sediment texture (Snelgrove et al. 1998, Hewitt et al. 2003), was clear, along with other factors such as temperature and potentially the organic matter availability (Incera et al. 2003) (not assessed in the present study).

Another important aspect to consider is that no clear seasonal differences were observed when analysing the species composition along the study period. The density decreased in the winter 2002 (February 2002), suggesting a seasonal variation that is usual in temperate systems (Lastra et al. 2006). Yet, for the spring/ summer period, the densities in 2002 (May to July) were comparatively lower than in 2001, only increasing again to similar values in autumn (October) 2002. This was quite evident, especially if ignoring the Siphonoecetes sp. density at 2 m deep in July 2002. When the seasonal variation in density is coupled with the physical parameters it is noticed that high energy periods, regarding wave climate and $\mathrm{D}_{\mathrm{c}}$, occurred until May 2002 (3 storms, $D_{c}$ of $6.6 \mathrm{~m}$ and $E_{x}$ of $350 \mathrm{~m}$ ). The observed change of the sediment texture, from a similar texture in June 2001 and February 2002 to a larger extending of the fine sands in June 2002, also indicates sediment disruption and transport across the profile, probably due to the action of waves. This suggests that in Faro, where mean wave energy is considered moderate and temperature range is small, episodes of great hydrodynamics (such as storms) have greater effects on the structure and dynamics of the macrobenthic community than seasonality, the effect of which appears to be relatively low.

\section{CONCLUSIONS}

Sub-littoral marine invertebrate communities support a high diversity of species with different ecological and life history traits. Species (with different adaptations) occupy different niches along a depth gradient, which, among other factors, varies with sediment texture and with their ability to cope with the physical environment. The present study showed a clear zonation of the subtidal macrobenthic community occurring with depth along a hydrodynamic impact gradient, from higher to lower hydrodynamic areas. On the other hand, a higher or lower extent of this impact on the macrobenthic community varies with temporal changes in wave climate (storms and wave height) and morphological parameters $\left(D_{c}\right.$ and $\left.E_{x}\right)$. Consistently, the higher the energy (translated into bottom disturbance) to which the macrobenthic community is subjected, the lower the number of species. Environmental severity conditioning the fauna is determined by the bottom disturbance, which in turn potentially affects sediment texture, food availability and biotic interactions. In temperate latitudes, the variability in the sandy macrobenthic communities is usually linked to the seasonal cycle, which includes community dynamics, species life cycle, water temperature and the occurrence of storm events. Yet, for the Faro system, the effect of seasonality appears relatively low and the storm events appeared to be a dominant factor conditioning the fauna, regardless of the season of occurrence.

Acknowledgements. Authors are indebted to Filipe Martinho, João Neto, Adriano Miguel, João Pedro Cascalho, Brad Morris, Catarina Sá-Pires and Daniel Pires, who participated in the fieldwork and the initial data processing. Wave data were kindly provided by the Instituto Hidrográfico de Portugal. This work was supported by the CROP project (PDCTM/P/MAR/15265/1999).

\section{LITERATURE CITED}

Beyst B, Buysse D, Dewicke A, Mees J (2001a) Surf zone hyperbenthos of Belgian sandy beaches: seasonal patterns. Estuar Coast Shelf Sci 53:877-895

Beyst B, Hostens K, Mees J (2001b) Factors influencing fish and macrocrustacean communities in the surf zone of sandy beaches in Belgium: temporal variation. J Sea Res 46:281-294

Brazeiro A (2001) Relationship between species richness and morphodynamics in sandy beaches: what are the underlying factors? Mar Ecol Prog Ser 224:35-44

Chícharo L, Regala J, Gaspar M, Alves F, Chícharo MA (2002) Macrofauna spatial differences within clam dredge-tracks and their implications for short-term fishing effects studies. Fish Res 54:349-353

Connor DW, Allen H, Golding N, Howell KL, Lieberknecht LM, Northen KO, Reker JB (2004) The marine habitat classification for Britain and Ireland version 04.05 . JNCC, Peterborough. Available at: www.jncc.gov.uk/ MarineHabitatClassification

Costa M, Silva R, Vitorino J (2001) Contribuição para o estudo do clima de agitação marítima na costa Portuguesa. 2as Jornadas Portuguesas de Engenharia Costeira e Portuária (CD-ROM). Laboratório Nacional de Engenharia Civil, Lisbon

Defeo O, McLachlan A (2005) Patterns, processes and regulatory mechanisms in sandy beach macrofauna: a multiscale analysis. Mar Ecol Prog Ser 295:1-20

Dernie KM, Kaiser MJ, Richardson EA, Warwick RM (2003) Recovery of soft sediment communities and habitats following physical disturbance. J Exp Mar Biol Ecol 285-286:415-434

Dolbeth M, Viegas I, Martinho F, Marques JC, Pardal MA (2006) Population structure and species dynamics of Spisula solida, Diogenes pugilator and Branchiostoma lanceolatum along a temporal-spatial gradient in the south coast of Portugal. Estuar Coast Shelf Sci 66:168-176 
Ferreira Ó, Martins JC, Dias JA (1997) Morfodinâmica e vulnerabilidade da Praia de Faro. Seminário sobre a Zona Costeira do Algarve, EUROCOAST:67-76

Gaspar MB, Castro M, Monteiro CC (1999) Effect of tooth spacing and mesh size on the catch of the Portuguese clam and razor clam dredge. ICES J Mar Sci 56:103-110

Hernández-Arana HA, Rowden AA, Attrill MJ, Warwick RM, Gold-Bouchot G (2003) Large-scale environmental influences on the benthic macroinfauna of the southern Gulf of Mexico. Estuar Coast Shelf Sci 58:825-841

Hewitt JE, Cummings VJ, Ellisa JI, Funnella G, Norkko A, Talley TS, Thrush SF (2003) The role of waves in the colonisation of terrestrial sediments deposited in the marine environment. J Exp Mar Biol Ecol 290:19-47

Hoey VG, Degraer S, Vincx M (2004) Macrobenthic community structure of the soft bottom sediments at the Belgian Continental Shelf. Estuar Coast Shelf Sci 59:599-613

Incera M, Cividanes SP, Lastra M, López J (2003) Temporal and spatial variability of sedimentary organic matter in sandy beaches on the northwest coast of the Iberian Peninsula. Estuar Coast Shelf Sci 58S:55-61

Janssen G, Mulder S (2005) Zonation of macrofauna across sandy beaches and surf zones along the Dutch coast. Oceanologia 47:265-282

Lastra M, de La Huz R, Sánchez-Mata AG, Rodil IF, Aerts K, Beloso S, López J (2006) Ecology of exposed sandy beaches in northern Spain: environmental factors controlling macrofauna communities. J Sea Res 55:128-140

McLachlan A, Dorvlo A (2005) Global patterns in sandy beach macrobenthic communities. J Coast Res 21(4):674-687

Miller DC, Muir CL, Hauser OA (2002) Detrimental effects of sedimentation on marine benthos: what can be learned from natural processes and rates? Ecol Eng 19:211-232

Morin JG, Kastendiek JE, Harrington A, Davis N (1985) Organization and patterns of interactions in a subtidal sand community on an exposed coast. Mar Ecol Prog Ser 27:163-185

Munilla T, Vicente CS (2005) Suprabenthic biodiversity of

Editorial responsibility: Otto Kinne (Editor-in-Chief),

Oldendorf/Luhe, Germany
Catalan beaches (NW Mediterranean). Acta Oecol 27: 81-91

Nicholls RJ, Birkemeier WA, Lee G (1998) Evaluation of depth of closure using data from Duck, NC, USA. Mar Geol 148: $179-201$

Reise K (2002) Sediment mediated species interactions in coastal waters. J Sea Res 48:127-141

Rodil IF, Lastra M (2004) Environmental factors affecting benthic macrofauna along a gradient of intermediate sandy beaches in northern Spain. Estuar Coast Shelf Sci 61: $37-44$

Rodil IF, Lastra M, Sánchez-Mata AG (2006) Community structure and intertidal zonation of the macroinfauna in intermediate sandy beaches in temperate latitudes: north coast of Spain. Estuar Coast Shelf Sci 67:267-279

Rosenberg R (1995) Benthic marine fauna structured by hydrodynamic processes and food availability. Neth J Sea Res 34:303-317

Sardá R, Pinedo S, Martin D (1999) Seasonal dynamics of macroinfaunal key species inhabiting shallow soft-bottoms in the Bay of Blanes (NW Mediterranean). Acta Oecol 20:315?326

Shepard FP (1954) Nomenclature based on sand-silt-clay ratios. J Sediment Petrol 24:151-158

Snelgrove PVR (1998) The biodiversity of macrofaunal organisms in marine sediments. Biodivers Conserv 7:1123-1132

Snelgrove PVR, Grassle JF, Butman CA (1998) Sediment choice by settling larvae of the the bivalve, Spisula solidissima (Dillwyn), in flow and still water. J Exp Mar Biol Ecol 231:171-190

Vicente CS, Sorbe JC (1999) Spatio-temporal structure of the suprabenthic community from the Creixell beach (western Mediterranean). Acta Oecol 20:377-389

Wieking G, Kröncke I (2003) Macrofauna communities of the Dogger Bank (central North Sea) in the late 1990s: spatial distribution, species composition and trophic structure. Helgol Mar Res 57:34-46

Submitted: December 6, 2006; Accepted: May 8, 2007

Proofs received from author(s): December 3, 2007 